\title{
Soya protein does not affect glycaemic control in adults with type 2 diabetes
}

\author{
Colleen P. Gobert ${ }^{1}$, Elizabeth A. Pipe ${ }^{1}$, Sarah E. Capes $^{2}$, Gerarda A. Darlington ${ }^{3}$, Johanna W. Lampe \\ and Alison M. Duncan ${ }^{1} *$ \\ ${ }^{1}$ Department of Human Health and Nutritional Sciences, University of Guelph, Guelph, Ont., Canada N1G 2W1 \\ ${ }^{2}$ Vancouver Island Health Authority, Vancouver, BC, Canada V8R $1 \mathrm{~J} 8$ \\ ${ }^{3}$ Department of Mathematics and Statistics, University of Guelph, Guelph, Ont., Canada N1G 2W1 \\ ${ }^{4}$ Fred Hutchinson Cancer Research Center, Seattle, WA 98109, USA
}

(Received 18 March 2009 - Revised 21 July 2009 - Accepted 27 July 2009 - First published online 26 August 2009)

Evidence from observational, animal and human studies supports a role for soya protein and its isoflavones in the improvement of glycaemic control in type 2 diabetes. The objective of the present study was to determine the effect of isoflavone-rich soya protein on markers of glycaemic control in adults with type 2 diabetes. Using a randomised, crossover, double-blind, placebo-controlled design, adults with diet-controlled type 2 diabetes ( $n$ 29) consumed soya protein isolate (SPI) and milk protein isolate (MPI) for $57 \mathrm{~d}$ each separated by a 4-week washout. Blood was collected on days 1 and 57 of each treatment period for analysis of fasting $\mathrm{HbA} 1 \mathrm{C}$, and fasting and postprandial glucose, insulin and calculated indices of insulin sensitivity and resistance. Urine samples of $24 \mathrm{~h}$ were collected at the end of each treatment period for analysis of isoflavones. Urinary isoflavone excretion was significantly greater following consumption of SPI compared with MPI, and $20.7 \%$ of the subjects $(n 6)$ were classified as equol excretors. SPI consumption did not significantly affect fasting or postprandial glucose or insulin, fasting HbA1C, or indices of insulin sensitivity and resistance. These data do not support a role for soya protein in the improvement of glycaemic control in adults with diet-controlled type 2 diabetes and contribute to a limited literature of human studies on the effects of soya protein on the management of type 2 diabetes.

Soya protein: Isoflavones: Type 2 diabetes: Glycaemic control

Type 2 diabetes is consistently recognised as a global epidemic ${ }^{(1-4)}$ with the estimation that by 2025 , the number of adult cases will have reached 300 million worldwide ${ }^{(5)}$. Diabetes complications lead to morbidity and mortality ${ }^{(6,7)}$, and not only impact quality of life, but also pose a significant economic burden ${ }^{(6,8)}$. Thus, strategies to improve diabetes management and reduce complications risk are worth investigation.

Appropriate management of type 2 diabetes can reduce complications through reduction in associated risk factors ${ }^{(9)}$. Reduction in hyperglycaemia is of particular importance such that a $1 \%$ reduction in $\mathrm{HbA} 1 \mathrm{C}$ is associated with a $21 \%$ reduced risk of diabetic complications ${ }^{(10)}$. Lifestyle is a well-recognised component of diabetes management, and improvements in glycaemic control have been demonstrated in adults with type 2 diabetes with a combination of pharmaceuticals and lifestyle changes ${ }^{(11)}$ and with lifestyle changes alone $^{(12)}$. Diet is a modifiable lifestyle factor that is a well-accepted component of diabetes management ${ }^{(9)}$. Numerous dietary components have been studied in relation to glycaemic control in adults with type 2 diabetes including carbohydrates $^{(13)}$, dietary fibre ${ }^{(14,15)}$, micronutrients ${ }^{(16)}$ and fatty acids ${ }^{(17,18)}$. A less traditional dietary component of interest to diabetes management is soya and its constituent protein and isoflavones.

Several lines of evidence support a role for soya in the improvement of glycaemic control. Cross-sectional studies document that the prevalence of type 2 diabetes among Japanese living in Tokyo (where soya consumption is high) is four times less than that of second-generation Japanese Americans living in the United States (where soya consumption is low $)^{(19,20)}$. More focused studies report that consumption of soya isoflavones ${ }^{(21)}$, soyabeans ${ }^{(22)}$ and soya foods ${ }^{(23)}$ is associated with reduced fasting and 2-h postglucose challenge serum insulin in postmenopausal women $^{(21)}$, reduced incidence of type 2 diabetes in middleaged Chinese women ${ }^{(22)}$ and reduced glycosuria in postmenopausal women ${ }^{(23)}$.

Animal studies in healthy and diabetic rat, mice and monkey models also provide support for a role of soya in diabetes management. In healthy rats, soya protein significantly reduced fasting glucose, fasting insulin and glucose area under the curve (AUC) following an intravenous glucose tolerance test ${ }^{(24)}$, significantly reduced serum insulin ${ }^{(25)}$

Abbreviations: AUC, area under the curve; $C_{\max }$, maximum concentration; HOMA-IR, homeostasis model assessment of insulin resistance; ISI ${ }_{\text {Matsuda, insulin }}$ sensitivity index-Matsuda; log, logarithm; QUICKI, quantitative insulin sensitivity check index; MPI, milk protein isolate; SPI, soya protein isolate; $T_{\text {max }}$, time to $C_{\text {max }}$.

* Corresponding author: Alison M. Duncan, fax +1 519763 5902, email amduncan@uoguelph.ca 
and significantly improved insulin secretion ${ }^{(26)}$. In healthy monkeys, soya protein significantly increased glucose effectiveness and insulin sensitivity ${ }^{(27)}$. In diabetic rats, soya protein significantly reduced $\mathrm{HbA} 1 \mathrm{C}^{(28)}$, maintained glycaemic control ${ }^{(29)}$ and increased GLUT4 expression ${ }^{(29)}$, PPAR gamma $(\operatorname{PPAR} \gamma)^{(29)}$ and antioxidant enzymes ${ }^{(28)}$. Finally, in diabetic mice, soya protein significantly reduced carbohydrate oxidation $^{(30)}$, fasting glucose $^{(31)}$ and fasting insulin(31); upregulated expression of insulin regulatory genes $^{(31)}$ and isoflavones significantly reduced fasting glucose and $\mathrm{HbA} 1 \mathrm{C}$ and improved glucose tolerance ${ }^{(32)}$.

The majority of human intervention studies that have investigated effects of soya in relation to type 2 diabetes have involved subjects who have diabetic complications ${ }^{(33-37)}$ and/or are taking glycaemic medications ${ }^{(38-43)}$. Early studies of adults with type 2 diabetes focused on soya fibre and demonstrated significant improvements in acute postprandial glucose $\mathrm{(44)}$ and glucose $\mathrm{AUC}^{(41)}$ after 4 weeks. Another study evaluated 6 weeks of a supplement that combined soya protein with soya fibre and found no significant effects on fasting glucose, insulin or $\mathrm{HbA} \mathrm{C}^{(39)}$. A number of studies have included subjects with diabetic nephropathy and demonstrated beneficial effects of soya protein on renal function $^{(33-35)}$, but not on fasting glucose or $\mathrm{HbA1C}$ following durations of $7^{(35)}-8^{(33)}$ weeks, except for a 4-year study that found significantly reduced fasting glucose ${ }^{(34)}$. Soya has also been shown to significantly reduce fasting glucose and HbA1C when consumed as part of a meal replacement for 3-12 months ${ }^{(38)}$. Related studies of isoflavone supplements have been primarily conducted in postmenopausal women with type 2 diabetes and consistently found no significant effects on fasting glucose ${ }^{(37,40,45)}$, insulin ${ }^{(37,45)}, \mathrm{HbA}^{(40,45)}$ or homeostasis model assessment of insulin resistance (HOMA-IR) $)^{(45)}$, following consumption of isoflavones at doses of $50 \mathrm{mg}$ for 4 weeks ${ }^{(40)}, 132 \mathrm{mg}$ for 12 weeks $^{(45)}$ or $177 \mathrm{mg}$ for 12 weeks $^{(37)}$. Most relevant to the present study is a study of thirty-two postmenopausal women with dietcontrolled type 2 diabetes in which 12 weeks of soya protein ( $30 \mathrm{~g}$ soya protein; $132 \mathrm{mg}$ isoflavones) significantly reduced fasting insulin, $\mathrm{HbA} 1 \mathrm{C}$ and insulin resistance when compared to cellulose ${ }^{(46)}$, albeit results could be attributed to the higher quantity (rather than different type) of protein in the soya protein treatment, consistent with evidence of beneficial effects of high-protein diets in subjects with type 2 diabetes ${ }^{(47-49)}$.

Evidence from epidemiological, animal and some human intervention studies that support a role for soya in diabetes management justifies a more focused human study, particularly in those without diabetic complications who are not taking glycaemic medications. Thus, the purpose of the present study was to compare the effect of soya protein isolate (SPI) with milk protein isolate (MPI) on markers of fasting and postprandial glycaemic control in adults with dietcontrolled type 2 diabetes.

\section{Methods \\ Subjects}

Subjects were adult ( $>19$ years old) males or postmenopausal females (no menstrual bleeding for at least 12 months or $>50$ years old with a hysterectomy) who were diagnosed with type
2 diabetes (fasting plasma glucose $\geq 7.0 \mathrm{mmol} / \mathrm{l}^{(9)}$ ) with stable glycaemic control (HbA1C $\leq 8 \%$ ), managing their diabetes with a stable diet (not currently undergoing dietary change) and medication stable (no changes in medications used) for at least 3 months. Subject exclusionary criteria included premenopausal women; BMI $>35 \mathrm{~kg} / \mathrm{m}^{2}$; use of oral hypoglycaemic agents, insulin therapy or lipid-lowering medications; occurrence of diabetic complications; use of hormone replacement therapy; alcohol consumption $>2$ drinks/d or $>7$ drinks/ week; antibiotic use within 3 months; allergy to soyabeans or milk; soya consumption of $>3$ servings/week; vegans.

Potential subjects were recruited using recruitment posters, emails, newspaper advertisements and support from local Diabetes Education Centres. Potential subjects were screened with a telephone/email eligibility questionnaire followed by an in-person meeting that included an in-depth eligibility questionnaire and discussion of the study details. Eligible and interested subjects received a study welcome letter and attended an orientation where they received a study handbook and were instructed on all study details. A total of thirty-four subjects started the study.

\section{Study design}

The study employed a randomised, crossover, double-blind, placebo-controlled design that consisted of two 57-d treatment periods separated by a $28-d$ washout period. Subjects visited the Human Nutraceutical Research Unit of the University of Guelph on days 1, 15, 29, 43 and 57 of each treatment period. The present study was conducted according to the guidelines laid down in the Declaration of Helsinki, and all procedures involving human subjects were approved by the University of Guelph Research Ethics Board (REB \#DE009). Written informed consent was obtained from all subjects.

\section{Sample size and treatment randomisation}

Sample size was estimated at twenty-two subjects for $\mathrm{HbA1C}$ and thirty-four subjects for glucose, using an effect size of $10 \%$, SD estimates of 1.19 for $\mathrm{HbA} 1 \mathrm{C}$ and 1.40 for glucose in accordance with the literature ${ }^{(13,14,39,46,47)}$, a power of $80 \%$, an $\alpha$ of 0.05 and two-sided testing (SPSS Sample Power, version 2.0; Teaneck, NJ, USA). The investigators randomised the participants to treatment order by placing equal numbers of the two possible treatment orders into an envelope and randomly selecting an order group for each participant as they started the study. Seventeen subjects were assigned to consume SPI followed by MPI, and seventeen participants were assigned to consume MPI followed by SPI. Both subjects and investigators were blinded to the treatments.

\section{Study treatments and diet}

The study treatments included a SPI and MPI beverage powder (Solae LLC, St Louis, MO, USA) that were provided in two $29 \mathrm{~g}$ packets/d. The treatment protein powders were comparable in energy and nutrient contents and contributed a daily total of $837 \mathrm{~kJ}, 8-9 \mathrm{~g}$ carbohydrate, $40 \mathrm{~g}$ protein from soya (SPI) or milk (MPI), $88 \mathrm{mg}$ (SPI) or $0 \mathrm{mg}$ (MPI) isoflavones (expressed as aglycone equivalents with an 
isoflavone distribution of $65 \%$ genistein, $31 \%$ daidzein and $4 \%$ glycitein), $1 \mathrm{~g}$ fat, $0-10 \mathrm{mg}$ cholesterol and $1400-$ $1600 \mathrm{mg}$ Ca. The SPI was made with SUPRO(R)SOY isolated soya protein with isoflavones. The SPI was water washed to preserve isoflavone content. The MPI was made with MPI (TMP 1240; New Zealand Milk Products, Inc., now Fonterra Brands America, Fort Lauderdale, FL, USA), in which casein and whey proteins were isolated together from milk (information provided by Solae LLC).

Subjects supplemented their habitual diets with the treatment protein powders and were provided with multiple examples of ways to consume them but encouraged to reconstitute them with water with the option of adding $\mathrm{Nestle}^{\mathrm{TM}}$ flavour packets. To avoid excess protein and $\mathrm{Ca}$ intakes, subjects were counselled by a registered dietitian to replace certain foods (e.g. milk, cheese, lunch meat) with their treatment protein powders. To create a more consistent exposure to the isoflavones within the SPI, subjects were instructed to consume their two treatment protein powder packets at separate times each day at least $4 \mathrm{~h}$ apart.

Subjects maintained their habitual lifestyle habits with specific dietary restrictions to minimise background phytooestrogen consumption including the avoidance of all soya products (soya lecithin and soya oil were permitted), flaxseed, beans, legumes and whole grains. Furthermore, since the treatment protein powders were fortified with $\mathrm{Ca}$, subjects were instructed to avoid fluid milk and Ca-fortified beverages. Subjects were also instructed to avoid all natural health products, protein bars, green tea and limit alcohol consumption to $<7$ drinks/week.

\section{Anthropometric and body measurements}

Baseline measurements obtained on study day 1 of treatment period 1 included height, blood pressure and heart rate. Height was measured without shoes, using a stadiometer (SECA Portable Stadiometer 214, Hanover, MD, USA). Sitting blood pressure was measured in duplicate on the left arm after $5 \mathrm{~min}$ of rest using an automatic blood pressure monitor (UA-767PC Blood Pressure Monitor; A\&D Medical, Milpitas, CA, USA).

Fasted body weight was measured on study days 1, 15, 29, 43 and 57 of each treatment period using a calibrated digital scale (SV 100; Acculab North America, Edgewood, NY, USA) with subjects wearing light clothes without shoes. BMI was calculated as body weight $(\mathrm{kg}) /$ height $\left(\mathrm{m}^{2}\right)$. Waist and hip circumferences were measured on study days 1 and 57 of each treatment period using a metric tape measure. Waist circumference was measured next to bare skin at the midway point between the iliac crest and the lower rib, and hip circumference was measured about the largest part of the buttocks next to light clothing. Body composition was measured on study days 1 and 57 of each treatment period using bioelectrical impedance analysis (BodyStat $1500^{\mathrm{TM}}$; BodyStat Ltd, Tampa, FL, USA). The procedure involved the subject resting in a supine position with two electrodes placed on their right hand (one below the first two knuckles and one on the wrist bone) and two electrodes placed on their right foot (one below the middle toe and one on the front of the ankle). To ensure proper hydration, subjects were instructed to consume at least $500 \mathrm{ml}$ of water in the
$12 \mathrm{~h}$ preceding their bioelectrical impedance analysis measurement.

\section{Food records}

Three-day food records were completed once before the study and on study days 2-4, 26-28 and 54-56 of each treatment period. Subjects were provided with predated sheets that included spaces to provide the time of consumption, amount and description of food and/or beverage. Subjects were trained to complete food records and encouraged to maximise detail, include brand names and submit package labels and recipes. Food records were analysed and averaged across each of the $3 \mathrm{~d}$ for intakes of energy, macronutrients, dietary fibre, cholesterol and $\mathrm{Ca}$ using ESHA Food Processor (version 9.81; ESHA Research, Salem, OR, USA).

\section{Study diaries}

Subjects were provided with a study diary for every day of each treatment period, in which they recorded information such as how and when they consumed their treatment powder, treatment powder tolerance issues or adverse effects, exercise, medications and any other information they deemed important. Study diaries were reviewed by a study coordinator at each study visit.

\section{Urine collection and analysis}

Three consecutive 24-h urine collections were completed on study days 54-56 of each treatment period. Urine was collected into opaque 3-litre plastic bottles (VWR International, West Chester, PA, USA) containing $3 \mathrm{~g}$ ascorbic acid and kept refrigerated. Subjects were also provided with a 1-litre plastic bottle $\left(\right.$ Nalgene $\left.^{\mathrm{TM}}\right)$, a lunch-size cooler bag and an ice pack for collection of urine in transport with instructions to transfer their urine to the 3-litre bottle. Volume of each 24-h urine collection was recorded, the collection was gently mixed and urine was aliquoted into $15 \mathrm{ml}$ conical tip polypropylene tubes $\left(\right.$ Sarstedt $^{\mathrm{TM}}$ ) and frozen at $-20^{\circ} \mathrm{C}$. Samples from every $24-\mathrm{h}$ urine collection were analysed for creatinine using an enzymatic UV method (Randox Laboratories Canada Ltd, Mississauga, Ont., Canada) on a Roche Hitachi 911 auto-analyzer with an inter-assay variability of $2 \cdot 85 \%$. Samples from every consecutive 3 -d urine collection were thawed and proportionally combined to create a pooled sample, which was analysed for isoflavones (genistein and daidzein) and isoflavone metabolites ( $O$-desmethylangolensin and equol) using GCMS as previously described ${ }^{(50)}$. Inter-assay variability was $3.1 \%$ for genistein, $4.2 \%$ for daidzein, $4.9 \%$ for $O$-desmethylangolensin and $4.0 \%$ for equol.

\section{Blood collection and analysis}

A fasted blood sample and an oral glucose tolerance test were completed on study days 1 and 57 of each treatment period. Subjects were instructed to avoid all food and beverages (except water that was encouraged) for $12 \mathrm{~h}$ prior and to avoid alcohol, strenuous activity and over-the-counter medications for $72 \mathrm{~h}$ before their blood samples. A catheter 
was inserted into the forearm antecubital vein by a qualified technician and kept patent with normal saline to facilitate periodic blood sampling. A baseline blood sample was collected into tubes containing EDTA, sodium heparin or no preservatives. Subjects then consumed $75 \mathrm{~g}$ of glucose solution (Trutol $^{\circledR} 75$; Nerl Diagnostics, East Providence, RI, USA), after which blood samples were collected at 15, 30, 60, 90, 120, 150 and $180 \mathrm{~min}$ into tubes containing sodium heparin or no preservatives. Blood containing EDTA (from the baseline fasting samples) was frozen at $-20^{\circ} \mathrm{C}$ until analysis for HbA1C using HPLC at Guelph General Hospital in Guelph, Ont., Canada. Inter-assay variation for $\mathrm{HbA1C}$ was $4.02 \%$. Blood containing sodium heparin was kept on ice until centrifugation at $1500 \mathrm{~g}$ at $5^{\circ} \mathrm{C}$ for $15 \mathrm{~min}$, after which plasma was aliquoted into cryovials and stored at $-80^{\circ} \mathrm{C}$ until analysis for glucose in duplicate using a YSI Model 2300 STAT PLUS Glucose Analyzer (YSI, Inc., Yellow Springs, OH, USA). Intra- and inter-assay variations for glucose were 0.91 and $2.07 \%$, respectively. Blood containing no preservatives was left at room temperature for $30 \mathrm{~min}$ before centrifugation at $1500 \mathrm{~g}$ at $5^{\circ} \mathrm{C}$ for $15 \mathrm{~min}$, after which serum was aliquoted into cryovials and stored at $-80^{\circ} \mathrm{C}$ until analysis in duplicate for insulin using a single antibody-coated tube RIA with ${ }^{125}$ I-labelled hormone (Coata-Count; Diagnostic Products Corporation, Los Angeles, CA, USA). Intra- and inter-assay variations for insulin were 2.28 and $13.8 \%$, respectively. To reduce effects of inter-assay variability in $\mathrm{HbA} 1 \mathrm{C}$, glucose and insulin, all samples from the same subject were analysed in the same batch.

\section{Data and statistical analyses}

AUC for glucose and insulin was calculated from the oral glucose tolerance test data using GraphPad Prism (GraphPad Software, Inc., San Diego, CA, USA). Surrogate indices of insulin sensitivity and resistance were calculated including the logarithm (log) of HOMA-IR ${ }^{(51)}$, quantitative insulin sensitivity check index (QUICKI) ${ }^{(52)}$ and insulin sensitivity index-Matsuda (ISI Matsuda $^{(51)}$. Maximum concentrations $\left(C_{\max }\right)$ and time to $C_{\max }\left(T_{\max }\right)$ were identified from the oral glucose tolerance test data for glucose and insulin. Insulin secretion was calculated using the method of Phillips et al. ${ }^{(53)}$.

All statistical analyses were performed using the Statistical Analysis System (version 9.1; Cary, NC, USA) with $P<0.05$ considered statistically significant. Data were examined for normality using stem leaf diagrams, box plots and residual plots, and it was determined that urinary isoflavones, fasting insulin, insulin AUC, insulin $C_{\text {max }}$, insulin $T_{\text {max }}$, log HOMA,

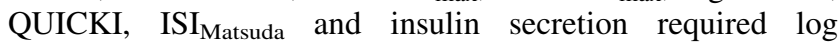
transformation.

The effect of study treatment on anthropometric data at study day 57 was determined using repeated-measures analysis of covariance including study day 1 values as a covariate and controlling for subject, treatment order and treatment, followed by the Tukey's test for multiple comparisons.

The effect of study treatment on energy and nutrient intake data was determined using repeated-measures ANOVA, controlling for subject, treatment order and treatment, followed by the Tukey's test for multiple comparisons.
The effect of study treatment on markers of glycaemic control values at study day 57 was determined using repeated-measures analysis of covariance including study day 1 values as a covariate and controlling for subject, treatment order and treatment, followed by the Tukey's test for multiple comparisons. To ensure the washout period was adequate, repeated-measures ANOVA was performed on study day 1 values for markers of glycaemic control, controlling for subject, treatment order and treatment. Markers of glycaemic control were further analysed to account for variation in urinary equol by inclusion of equol excretor status as a covariate and the interaction between equol excretor status and treatment in the statistical model.

\section{Results}

\section{Subject withdrawals and exclusions}

During the study, four subjects withdrew due to dislike of the study treatment powders $(n 1)$, cancer diagnosis $(n 1)$ and personal issues ( $n$ 2). After the study, data from one subject were excluded due to a baseline $\mathrm{HbA} 1 \mathrm{C}>8 \%$. A total of twenty-nine subjects (sixteen males and thirteen females) were included in the statistical analysis, out of which fourteen subjects consumed SPI followed by MPI and fifteen subjects consumed MPI followed by SPI. All subjects consumed the SPI and MPI treatments every day during each treatment period with no reports of tolerance issues or adverse effects.

\section{Subject characteristics}

Subject characteristics at baseline are presented in Table 1. Subjects had good glycaemic control (baseline fasting plasma glucose of $6.76 \mathrm{mmol} / \mathrm{l}$ and $\mathrm{HbA} 1 \mathrm{C}$ of $5.89 \%$ ), were not taking any medications to modulate glycaemic control or lipids and were taking an average of 1.80 medications with the top three types being ace inhibitors ( $n$ 8), aspirin ( $n$ 6) and $\beta$-blockers ( $n$ 5). Subject characteristics during the study are presented in Table 2 and show that there were no significant differences in body weight, BMI, body fat, waist or hip circumferences or waist:hip ratio between the SPI and MPI treatments.

Table 1. Baseline subject characteristics (Mean values and standard deviations, $n$ 29)

\begin{tabular}{lcc}
\hline & Mean & SD \\
\hline Age (years) & 60.1 & 9.64 \\
Body weight $(\mathrm{kg})$ & 83.4 & 10.9 \\
BMl (kg/m ${ }^{2}$ ) & 29.6 & 4.07 \\
Body fat (\%) & 38.5 & 10.1 \\
Waist circumference (cm) & 99.0 & 7.48 \\
Hip circumference (cm) & 109.2 & 8.05 \\
Waist:hip ratio & 0.92 & 0.07 \\
Blood pressure (mmHg) & & \\
Systolic & 134.7 & 16.1 \\
Diastolic & 83.7 & 8.51 \\
Heart rate (beats/min) & 65.9 & 8.49 \\
Time since diagnosis (months) & 40.8 & 57.3 \\
Number of medications $(n)$ & 1.80 & 0.95 \\
Fasting plasma glucose (mmol/l) & 6.76 & 1.30 \\
HbA1C (\%) & 5.89 & 0.62 \\
\hline
\end{tabular}


Table 2. Subject characteristics during the study

(Mean values and standard deviations, $n$ 29)

\begin{tabular}{|c|c|c|c|c|c|c|c|c|}
\hline & \multicolumn{4}{|c|}{ MPI } & \multicolumn{4}{|c|}{ SPI } \\
\hline & \multicolumn{2}{|c|}{ Day 1} & \multicolumn{2}{|c|}{ Day 57} & \multicolumn{2}{|c|}{ Day 1} & \multicolumn{2}{|c|}{ Day 57} \\
\hline & Mean & SD & Mean & SD & Mean & SD & Mean & SD \\
\hline Body weight $(\mathrm{kg})$ & $83 \cdot 4$ & $10 \cdot 9$ & $83 \cdot 2$ & $10 \cdot 4$ & $83 \cdot 1$ & 10.5 & $83 \cdot 1$ & $10 \cdot 2$ \\
\hline BMI $\left(\mathrm{kg} / \mathrm{m}^{2}\right)$ & 29.5 & 3.77 & 29.4 & 3.75 & $29 \cdot 3$ & 3.59 & 29.2 & 3.62 \\
\hline Body fat (\%) & $38 \cdot 0$ & $10 \cdot 8$ & 37.5 & 12.4 & $37 \cdot 3$ & $9 \cdot 31$ & $36 \cdot 2$ & $10 \cdot 6$ \\
\hline Waist circumference $(\mathrm{cm})$ & $98 \cdot 8$ & $7 \cdot 77$ & 99.2 & $7 \cdot 23$ & $98 \cdot 6$ & $7 \cdot 72$ & $99 \cdot 1$ & 8.03 \\
\hline Hip circumference $(\mathrm{cm})$ & $109 \cdot 7$ & 8.29 & $108 \cdot 2$ & $8 \cdot 16$ & $108 \cdot 0$ & 8.02 & $107 \cdot 7$ & 7.56 \\
\hline Waist:hip ratio & 0.91 & 0.07 & 0.92 & 0.06 & 0.91 & 0.06 & 0.92 & 0.05 \\
\hline
\end{tabular}

MPI, milk protein isolate; SPI, soya protein isolate.

\section{Energy and nutrient intakes}

Protein $(P<0 \cdot 0001)$ and $\mathrm{Ca}(P<0 \cdot 0001)$ intakes were significantly higher during the study compared with before the study (Table 3). During the study, with the exception of SFA, which was significantly lower during the SPI compared with the MPI treatment $(P=0 \cdot 04)$, there were no significant differences between the SPI and MPI treatments in intakes of energy, macronutrients, dietary fibre, cholesterol or $\mathrm{Ca}$ (Table 3).

\section{Urinary isoflavone excretion}

Urinary excretion of genistein, daidzein and $O$-desmethylangolensin were significantly higher following consumption of the SPI compared to the MPI $(P<0.0001$; Table 4). Further analysis of urinary equol data within the SPI treatment showed that six subjects $(20.7 \%$ of subjects $)$ could be classified as equol excretors (equol excretion $>1000 \mathrm{nmol} / \mathrm{l}^{(54)}$ ) and twenty-three subjects could be classified as equol nonexcretors. Among the equol excretors, urinary equol excretion was significantly higher following consumption of the SPI compared to the MPI $(P<0 \cdot 0001$; Table 4$)$.

\section{Markers of glycaemic control}

There were no significant differences in day 1 concentrations of fasting plasma glucose, $\mathrm{HbA} 1 \mathrm{C}$, glucose $C_{\max }$, glucose $T_{\max }$ (Table 5), postprandial glucose (Fig. 1(a)), glucose AUC (Fig. 1(a)), fasting serum insulin, insulin $C_{\max }$, insulin $T_{\max }$,

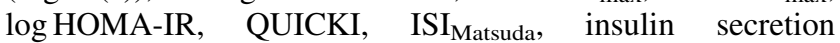
(Table 5), postprandial insulin (Fig. 2(a)) or insulin AUC (Fig. 2(a)), providing evidence that the washout period between treatments was sufficient.

Plasma glucose parameters, including fasting glucose, HbA1C, glucose $C_{\max }$, glucose $T_{\max }$ (Table 5), postprandial glucose (Fig. 1(b)) and glucose AUC (Fig. 1(b)), were not significantly affected by consumption of SPI compared with MPI. Similarly, serum insulin parameters, including fasting insulin, insulin $C_{\max }$, insulin $T_{\max }, \log$ HOMA-IR, QUICKI,

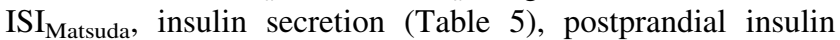
(Fig. 2(b)) and insulin AUC (Fig. 2(b)), were not significantly affected by consumption of SPI compared with MPI. Inclusion of equol excretor status as a covariate in the statistical model did not change any of the results, and there was no significant interaction between equol excretor status and treatment for any of the markers of glycaemic control.

Table 3. Dietary intake during the study

(Mean values and standard deviations, $n$ 29)

\begin{tabular}{|c|c|c|c|c|c|c|}
\hline & \multicolumn{2}{|c|}{ Pre-study* } & \multicolumn{2}{|c|}{ MPI† } & \multicolumn{2}{|c|}{ SPIt } \\
\hline & Mean & SD & Mean & SD & Mean & SD \\
\hline Energy (kJ) & 8322 & 2457 & 8950 & 2597 & 8598 & 2149 \\
\hline Protein $(\mathrm{g})$ & $87 \cdot 3^{\mathrm{a}}$ & $22 \cdot 6$ & $120 \cdot 1^{b}$ & 28.4 & $118.6^{b}$ & 20.0 \\
\hline Carbohydrates (g) & 239.7 & 73.1 & 237.4 & 81.4 & $230 \cdot 2$ & $67 \cdot 2$ \\
\hline Total fat $(\mathrm{g})$ & $75 \cdot 6$ & 33.5 & $78 \cdot 8$ & 30.9 & 73.4 & $26 \cdot 9$ \\
\hline SFA & $22 \cdot 0^{a, b}$ & 10.5 & $24 \cdot 4^{a}$ & 11.7 & $22 \cdot 2^{\mathrm{b}}$ & 8.43 \\
\hline MUFA & $22 \cdot 3$ & $14 \cdot 3$ & $21 \cdot 2$ & $10 \cdot 3$ & $20 \cdot 7$ & 11.0 \\
\hline PUFA & $10 \cdot 7$ & 5.46 & $10 \cdot 3$ & $4 \cdot 31$ & $10 \cdot 1$ & $5 \cdot 18$ \\
\hline Dietary fibre (g) & 24.6 & 8.50 & 24.0 & 9.68 & $22 \cdot 8$ & $7 \cdot 71$ \\
\hline Cholesterol (g) & 253.0 & $132 \cdot 4$ & $276 \cdot 1$ & $148 \cdot 3$ & 261.1 & $97 \cdot 6$ \\
\hline $\mathrm{Ca}(\mathrm{mg})$ & $920 \cdot 7^{\mathrm{a}}$ & $442 \cdot 3$ & $1959^{b}$ & 456.0 & $2002^{b}$ & 462.6 \\
\hline
\end{tabular}

MPI, milk protein isolate; SPI, soya protein isolate.

${ }_{a, b}$ Mean values within a row with unlike superscript letters were significantly different $(P<0 \cdot 05)$.

*Values are based on the results of one 3-d food record completed before the study.

† Values are based on the average results of three 3-d food records completed on days 2-4, 26-28 and 54-56 and include contributions from the study treatment powders. 
Table 4. Urinary isoflavone excretion after consumption of MPI and SPI (Geometric mean values and $95 \%$ confidence intervals, $n 29)^{*}$

\begin{tabular}{lccccr}
\hline & \multicolumn{3}{c}{ MPI } & & \multicolumn{2}{c}{ SPI } \\
\cline { 2 - 3 } \cline { 5 - 6 } \cline { 5 - 6 } & Geometric mean & $95 \% \mathrm{Cl}$ & & Geometric mean & \multicolumn{1}{c}{$95 \% \mathrm{Cl}$} \\
\hline Genistein $(\mathrm{nmol} / 24 \mathrm{~h})$ & $90 \cdot 9^{\mathrm{a}}$ & $44 \cdot 4,186 \cdot 2$ & & $11849^{\mathrm{b}}$ & 9855,14247 \\
Daidzein $(\mathrm{nmol} / 24 \mathrm{~h})$ & $134 \cdot 3^{\mathrm{a}}$ & $65 \cdot 6,275 \cdot 0$ & & $13767^{\mathrm{b}}$ & 12175,15567 \\
ODMA $(\mathrm{nmol} / 24 \mathrm{~h})$ & $31 \cdot 8^{\mathrm{a}}$ & $17 \cdot 9,56 \cdot 5$ & & $7708^{\mathrm{b}}$ & 3842,15465 \\
Equol $(\mathrm{nmol} / 24 \mathrm{~h}) \dagger$ & $21 \cdot 8^{\mathrm{a}}$ & $17 \cdot 4,27 \cdot 3$ & & $12965^{\mathrm{b}}$ & 10140,16577 \\
\hline
\end{tabular}

MPI, milk protein isolate; SPI, soya protein isolate; ODMA, O-desmethylangolensin.

${ }^{a, b}$ Mean values within a row with unlike superscript letters were significantly different $(P<0.0001)$.

* Data were log-transformed before statistical analysis and presented as geometric mean $(95 \% \mathrm{Cl})$.

†Data are presented for equol excretors only $(n 6)$.

\section{Discussion}

The purpose of the present study was to determine the effect of soya protein on markers of glycaemic control in adults with diet-controlled type 2 diabetes. The present study is unique as it included subjects with diet-controlled type 2 diabetes who were not on glycaemic medications, a treatment and control group with equal amounts of protein and an evaluation of fasting and postprandial glycaemic response. Subjects had been diagnosed with type 2 diabetes for an average duration of 40.8 months, and their average baseline fasting plasma glucose of $6.76 \mathrm{mmol} / \mathrm{l}$ and $\mathrm{HbA} 1 \mathrm{C}$ of $5.89 \%$ indicated good diabetes management ${ }^{(9)}$ and made them candidate to explore the potential for soya to prevent risk of diabetes complications.

Anthropometric measurements did not significantly change during the present study. Since weight loss in general, and abdominal fat loss in particular, can improve glycaemic control in type 2 diabetes ${ }^{(55)}$, the lack of significant changes in these measures reduced any potential confounding effects on the study's primary glycaemic control endpoints. Analysis of 3-d food records revealed that protein and $\mathrm{Ca}$ intakes were significantly higher during the study compared with before the study, which was expected due to the $40 \mathrm{~g}$ protein and $1400-1600 \mathrm{mg} \mathrm{Ca}$ content of the daily study treatment powder. Since increased protein intake can improve glycaemic control in type 2 diabetes ${ }^{(47-49)}$, the lack of significant difference in protein intake between the SPI and MPI treatments allowed for a focus on protein type rather than amount. Ca intakes were also not significantly different between treatments minimising any potential confounding effects of $\mathrm{Ca}$ on glycaemic control ${ }^{(56)}$.

Urinary isoflavone excretion was significantly higher following consumption of the SPI compared with the MPI, providing evidence that subjects consumed the SPI during the SPI treatment period and avoided external sources of phyto-oestrogens during the MPI treatment period. Urinary equol data revealed that six out of the twenty-nine subjects $(20.7 \%)$ could be classified as equol excretors, which is lower than the $28-50 \%$ prevalence rates observed in studies of adults without diabetes ${ }^{(54,57-60)}$. Prevalence of equol excretor status has not been identified in previous studies of adults with type 2 diabetes; however, a study of adults with type 1 diabetes reported that increasing concentration of serum equol was associated with increasing severity of renal

Table 5. Plasma glucose and serum insulin parameters before and after consumption of MPI and SPI (Mean values and $95 \%$ confidence intervals, $n$ 29)

\begin{tabular}{|c|c|c|c|c|c|c|c|c|}
\hline & \multicolumn{4}{|c|}{ MPI } & \multicolumn{4}{|c|}{ SPI } \\
\hline & \multicolumn{2}{|c|}{ Day 1} & \multicolumn{2}{|c|}{ Day 57} & \multicolumn{2}{|c|}{ Day 1} & \multicolumn{2}{|c|}{ Day 57} \\
\hline & Mean & $95 \% \mathrm{Cl}$ & Mean & $95 \% \mathrm{Cl}$ & Mean & $95 \% \mathrm{Cl}$ & Mean & $95 \% \mathrm{Cl}$ \\
\hline Fasting plasma glucose (mmol/l) & 6.92 & $6 \cdot 41,7.43$ & $6 \cdot 89$ & $6 \cdot 46,7 \cdot 32$ & $6 \cdot 73$ & $6 \cdot 24,7 \cdot 22$ & $7 \cdot 01$ & $6.50,7.52$ \\
\hline $\mathrm{HbA} 1 \mathrm{C}(\%)$ & 5.94 & $5 \cdot 69,6 \cdot 19$ & 5.97 & $5 \cdot 74,6 \cdot 20$ & 5.92 & $5 \cdot 67,6 \cdot 17$ & 5.91 & $5 \cdot 66,6 \cdot 16$ \\
\hline \multicolumn{9}{|l|}{ Postprandial plasma glucose } \\
\hline Plasma glucose $C_{\max }(\mathrm{mmol} / \mathrm{l})$ & $14 \cdot 2$ & $13 \cdot 0,15 \cdot 5$ & $14 \cdot 3$ & $13 \cdot 2,15 \cdot 3$ & $14 \cdot 0$ & $12 \cdot 8,15 \cdot 3$ & $14 \cdot 1$ & $12 \cdot 9,15 \cdot 3$ \\
\hline Plasma glucose $T_{\max }(\min )$ & 73.5 & $65 \cdot 1,81 \cdot 9$ & $82 \cdot 8$ & $71.5,94 \cdot 0$ & 73.5 & $63 \cdot 1,83 \cdot 8$ & $80 \cdot 7$ & $72 \cdot 6,88 \cdot 8$ \\
\hline Fasting serum insulin $(\mathrm{pmol} / \mathrm{l})^{*}$ & $66 \cdot 0$ & $54.9,79.4$ & $69 \cdot 4$ & $56 \cdot 6,85 \cdot 2$ & $61 \cdot 6$ & $50 \cdot 2,75 \cdot 6$ & $61 \cdot 6$ & $50 \cdot 2,75 \cdot 6$ \\
\hline \multicolumn{9}{|l|}{ Postprandial serum insulin } \\
\hline Serum insulin $C_{\max }(\mathrm{pmol} / \mathrm{l})^{*}$ & 554.5 & $433 \cdot 7,708 \cdot 9$ & $501 \cdot 7$ & $376 \cdot 6,668 \cdot 3$ & $522 \cdot 2$ & $400 \cdot 1,681 \cdot 5$ & $477 \cdot 2$ & $373 \cdot 3,610 \cdot 2$ \\
\hline Serum insulin $T_{\max }(\min )^{*}$ & 86.5 & $74 \cdot 9,99 \cdot 8$ & $91 \cdot 8$ & $81 \cdot 2,103 \cdot 8$ & $94 \cdot 6$ & $82 \cdot 0,109 \cdot 2$ & $102 \cdot 5$ & $92 \cdot 5,113.6$ \\
\hline $\log (\mathrm{HOMA})^{\star}$ & 2.94 & $2 \cdot 40,3.61$ & $3 \cdot 10$ & $2.47,3.88$ & $2 \cdot 64$ & $2 \cdot 11,3.30$ & 2.77 & $2 \cdot 26,3.40$ \\
\hline QUICKI $^{*}$ & 0.24 & $0.23,0.26$ & 0.24 & $0.23,0.25$ & 0.25 & $0.23,0.26$ & 0.24 & $0.23,0.26$ \\
\hline $\mathrm{ISI}_{\text {Matsuda }}{ }^{*}$ & 3.53 & $2 \cdot 87,4.33$ & 3.53 & $2 \cdot 87,4 \cdot 33$ & 3.78 & $2.96,4.83$ & 3.82 & $3.05,4.78$ \\
\hline Insulin secretion* & 5.53 & $3.67,8.33$ & $5 \cdot 26$ & $3.87,7 \cdot 15$ & $5 \cdot 26$ & $3.79,7 \cdot 30$ & 4.71 & $3 \cdot 19,6 \cdot 95$ \\
\hline
\end{tabular}

MPI, milk protein isolate; SPI, soya protein isolate; $C_{\max }$, maximum concentration; $T_{\max }$, time to $C_{\max }$; HOMA, homeostasis model assessment; QUICKI, quantitative insulin sensitivity check index; ISI Matsuda, insulin sensitivity index-Matsuda.

${ }^{\star}$ Data were log-transformed before statistical analysis and presented as geometric mean $(95 \% \mathrm{Cl})$. 

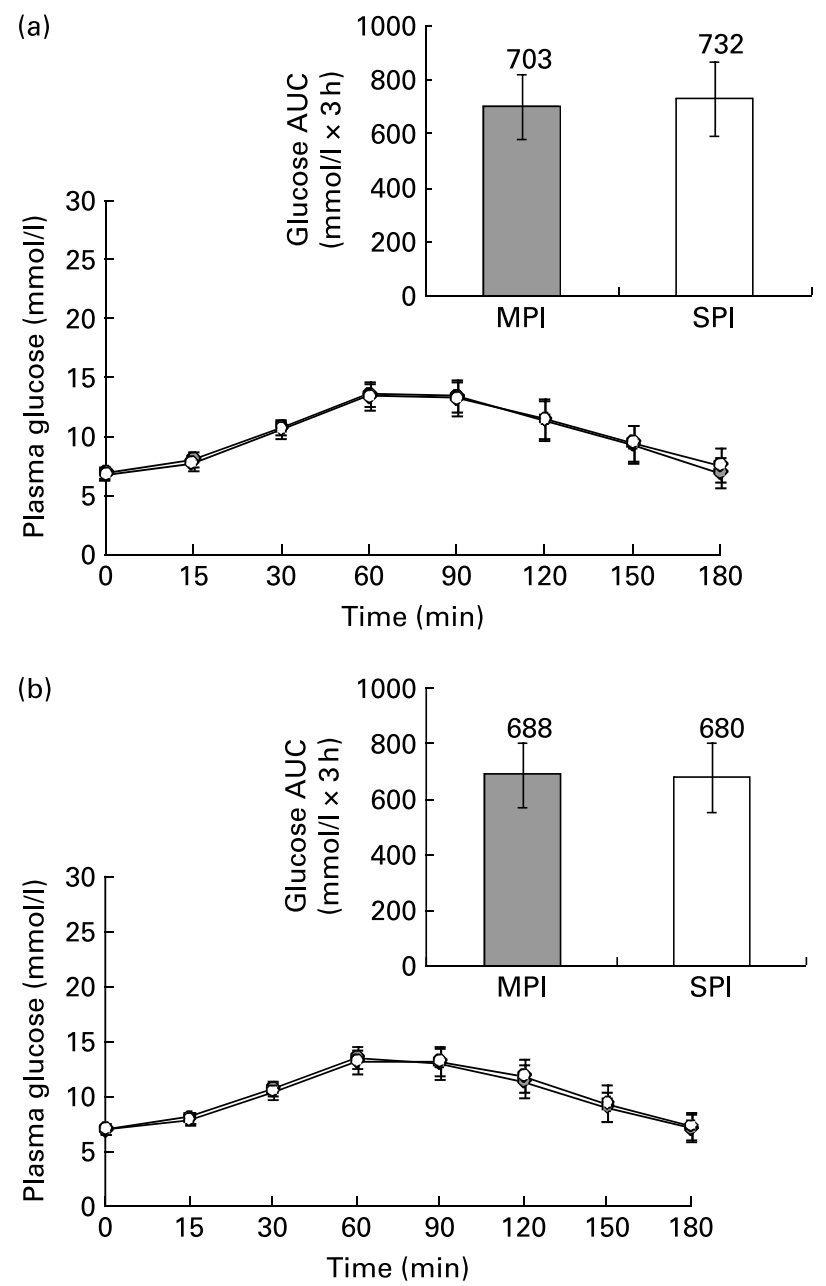

Fig. 1. Postprandial plasma glucose. Data are means and $95 \% \mathrm{Cl}(n$ 29) presented at each time point in the line graphs and summarised across time points as area under the curve (AUC) in the bar graphs. (a) Data from day 1 and (b) data from day 57. MPI, milk protein isolate (-O-); SPI, soya protein isolate $(-\circ)$.

disease $^{(61)}$. The equol excretion data of the present study warrant further exploration of equol production in type 2 diabetes.

Fasting or postprandial glucose was not significantly affected by 8 weeks of SPI ( $40 \mathrm{~g}$ soya protein and $80 \mathrm{mg}$ isoflavones) relative to MPI ( $40 \mathrm{~g}$ protein) in the present study. This is consistent with previous studies of adults with type 2 diabetes, which have found no significant effect on fasting glucose with consumption of a soya protein and fibre supplement ( $50 \mathrm{~g}$ soya protein, $165 \mathrm{mg}$ isoflavones and $20 \mathrm{~g}$ soya fibre) for 6 weeks ${ }^{(39)}$, soya foods $(0.5 \mathrm{~g}$ soya protein $/ \mathrm{kg}$ body weight/d, mg isoflavones not reported) for 8 weeks ${ }^{(36)}$, soya protein $(30 \mathrm{~g}$ SPI and $132 \mathrm{mg}$ isoflavones for 12 weeks $^{(46)}, 35 \%$ of daily protein as soya, $\mathrm{mg}$ isoflavones not reported for 7 weeks ${ }^{(35)}$ or $0.5 \mathrm{~g} \mathrm{SPI} / \mathrm{kg}$ body weight $/ \mathrm{d}$, $\mathrm{mg}$ isoflavones not reported for 8 weeks $^{(33)}$ ) or isoflavone supplements $\left(50 \mathrm{mg}\right.$ for 4 weeks $^{(40)}, 132 \mathrm{mg}$ for 12 weeks $^{(45)}$ or $177 \mathrm{mg}$ for 12 weeks $\left.{ }^{(37)}\right)$. In contrast, other studies of adults with type 2 diabetes have found significant reductions in fasting glucose following consumption of soya protein meal (12 $\mathrm{g}$ soya protein and $50 \mathrm{mg}$ isoflavones) for
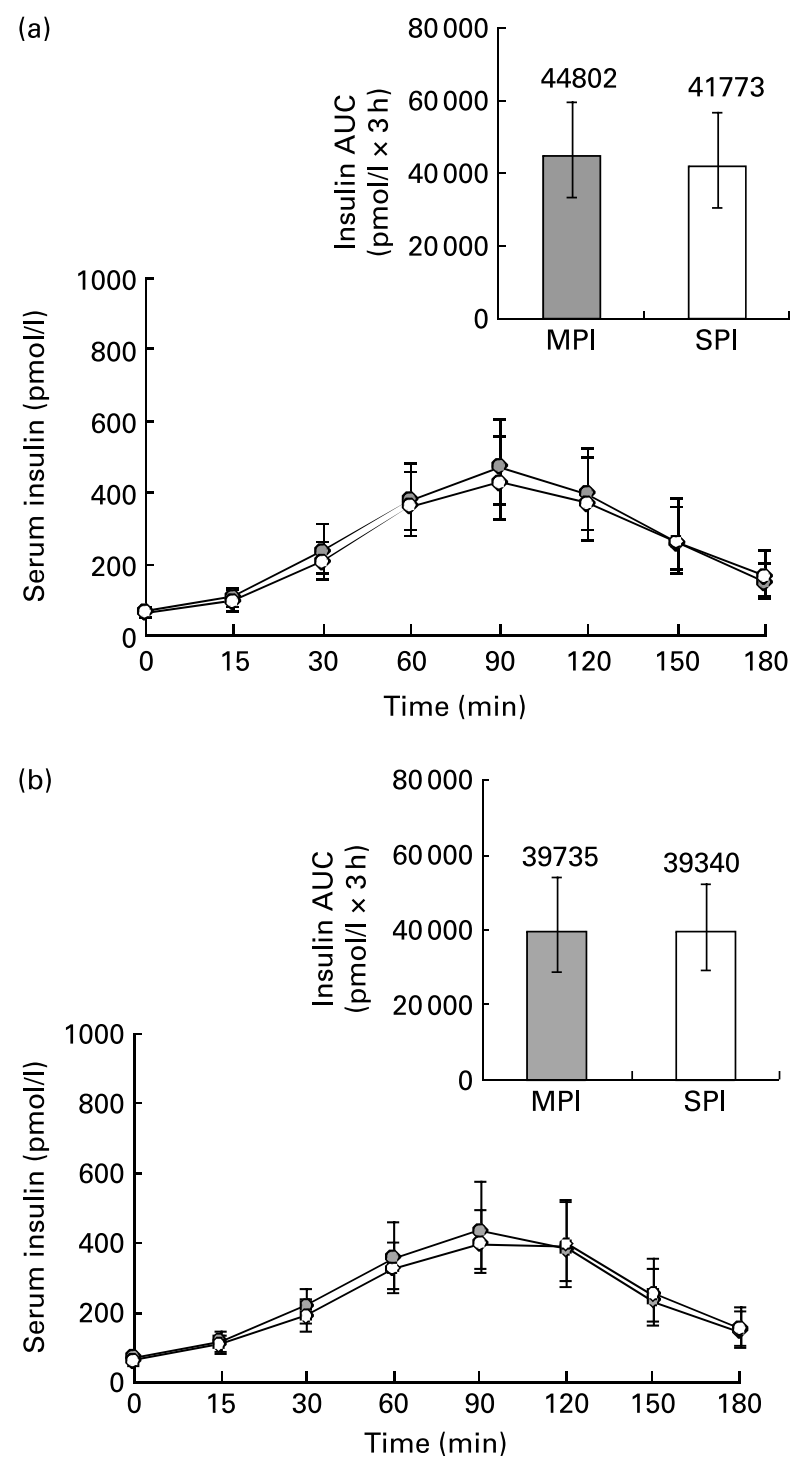

Fig. 2. Postprandial serum insulin. Data were log-transformed before statistical analysis and are geometric means and $95 \% \mathrm{Cl}(n 29)$ presented at each time point in the line graphs and summarised across time points as area under the curve (AUC) in the bar graphs. (a) Data from day 1 and (b) data from day 57. MPI, milk protein isolate (-O-); SPI, soya protein isolate (-O-).

3 months $^{(43)}$, a soya protein supplement $(5 \cdot 22 \mathrm{~g}$ soya protein, $\mathrm{mg}$ isoflavones not reported) for 12 weeks $^{(42)}$, soya protein (14-17g soya protein and $36-48 \mathrm{mg}$ isoflavones) for 4 years $^{(34)}$ and a soya-based meal replacement (amounts of soya protein and isoflavones not reported) for 3 and 6 , but not 12 months ${ }^{(38)}$.

$\mathrm{HbA1C}$ was also not significantly affected by 8 weeks of SPI relative to MPI in the present study. This is consistent with previous studies of adults with type 2 diabetes, which have also found no significant change in $\mathrm{HbA1C}$ following consumption of a soya and fibre supplement $(50 \mathrm{~g}$ soya protein, $165 \mathrm{mg}$ isoflavones and $20 \mathrm{~g}$ soya fibre) for 6 weeks ${ }^{(39)}$, diets containing soya protein for $7-8$ weeks $^{(33,35,36)}$ or an isoflavone supplement $\left(50 \mathrm{mg}\right.$ for 4 weeks $^{(40)}$ or $132 \mathrm{mg}$ for 12 weeks $^{(45)}$ ). However, other studies of adults with type 2 diabetes have reported significant reductions in $\mathrm{HbA} 1 \mathrm{C}$ 
following consumption of SPI ( $30 \mathrm{~g}$ soya protein and $132 \mathrm{mg}$ isoflavones) for 12 weeks ${ }^{(46)}$, a soya-based meal replacement for 12 months $^{(38)}$ and soya protein meal (12 g soya protein and $50 \mathrm{mg}$ isoflavones) for 3 months ${ }^{(43)}$. Since HbA1C most accurately reflects glycaemic control in the previous 2-3 months ${ }^{(62)}$, it is possible that the 8 -week treatment period of the present study was insufficient to reveal an effect. Although dietary interventions in adults with type 2 diabetes have demonstrated significant reductions in $\mathrm{HbA1C}$ after 4 weeks ${ }^{(47,63)}$, the only soya interventions to do so have been of $3^{(43,46)}$ and $12^{(38)}$ month durations.

Fasting or postprandial insulin was also not significantly affected by 8 weeks of SPI relative to MPI in the present study. This is consistent with previous studies of adults with type 2 diabetes, which have also found no significant change in fasting insulin following consumption of an acute meal with $10 \mathrm{~g}$ soya polysaccharide ${ }^{(44)}$, a soya and fibre supplement ( $50 \mathrm{~g}$ soya protein, $165 \mathrm{mg}$ isoflavones and $20 \mathrm{~g}$ soya fibre) for 6 weeks $^{(39)}$, a soya-based meal replacement for 3-12 months $^{(38)}$ or isoflavone supplements $\left(132 \mathrm{mg}^{(45)}\right.$ or $177 \mathrm{mg}^{(37)}$ ) for 12 weeks. In contrast, fasting insulin has been significantly reduced in adults with type 2 diabetes following consumption of SPI ( $30 \mathrm{~g}$ soya protein and $132 \mathrm{mg}$ isoflavones) for 12 weeks $^{(46)}$. It is relevant that degree of impairment in insulin secretion and/or resistance will vary ${ }^{(9)}$ and influence interpretation, such that decreased insulin would be favourable in those with insulin resistance and increased insulin would be favourable in those with impaired insulin secretion. Thus, heterogeneity of disease progression among subjects could cause variation that precludes clear demonstration of an effect.

The present study calculated log HOMA-IR as a measure of insulin sensitivity and found that it was not significantly affected by 8 weeks of SPI, consistent with a previous study of postmenopausal women with type 2 diabetes who consumed a $132 \mathrm{mg}$ isoflavone supplement for 12 weeks $^{(45)}$. In contrast, HOMA-IR was significantly reduced in postmenopausal women with diet-controlled type 2 diabetes who consumed SPI ( $30 \mathrm{~g}$ soya protein and $132 \mathrm{mg}$ isoflavones) for 12 weeks $^{(46)}$ and in postmenopausal women with metabolic syndrome who consumed soya protein ( $15 \mathrm{~g}$ soya protein and $84 \mathrm{mg}$ isoflavones) or soya nuts $(11.3 \mathrm{~g}$ soya protein and $102 \mathrm{mg}$ isoflavones) for 8 weeks $^{(64)}$.

The present study also calculated other indices of glycaemic control (glucose and insulin $C_{\max }$ and $T_{\max }$, QUICKI,

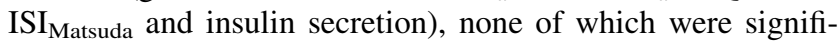
cantly affected by 8 weeks consumption of SPI relative to MPI. These indices have not been included in other soya intervention studies in adults with type 2 diabetes, yet their reflection of the postprandial glycaemic response and correlation with $\mathrm{HbA} 1 \mathrm{C}^{(65)}$ justify their inclusion in future studies.

Overall, soya intervention studies that have examined glycaemic control in adults with type 2 diabetes have yielded inconsistent results. Variation can come from study design, particularly if there is a lack of control group ${ }^{(37,42,43)}$. Variation can also come from the treatment and control groups themselves such as the combination of soya protein and isoflavones with soya fibre ${ }^{(39)}$, the mismatch of protein content between the soya treatment and control ${ }^{(46)}$ or the possibility that other soyabean components (besides protein, isoflavones and fibre) were not accounted for, yet may influence glycaemic control; for example, pinitol isolated from soyabeans has been shown to significantly reduce postprandial glucose when consumed before a rice meal in adults with type 2 diabetes ${ }^{(66)}$. Finally, variation can come from differences in baseline concentrations of glucose, insulin and HbA1C. Soya intervention studies of adults with type 2 diabetes, which have found significant improvements in glucose $^{(34,38,42,43)}$, $\mathrm{HbA} 1 \mathrm{C}^{(38,43,46)}$ or insulin ${ }^{(46)}$, have had baseline values of glucose of $7.29-9.79 \mathrm{mmol} / \mathrm{l}^{(34,42,43,46)}$, HbA1C of $6.83-$ $9.60 \%{ }^{(38,43,46)}$ and insulin of $116 \cdot 0 \mathrm{pmol} / \mathrm{l}^{(46)}$

There are limitations of the present study, which deserve mention. Subjects were not representative of all those with type 2 diabetes in that they were managing their diabetes without insulin or medications and had good glycaemic control, which contrasts a Canadian study of adults with type 2 diabetes documenting glycaemic medication use at $73 \%$ and average HbA1C of $7 \cdot 3 \%{ }^{(67)}$. Furthermore, although the 8 -week treatment duration was employed to minimise the likelihood that a subject would need to initiate oral hypoglycaemic medications and to reduce the subject burden of total intervention duration, it may not have been sufficient to detect significant effects. Finally, since the sample size calculation estimated a need for thirty-four subjects to detect changes in plasma glucose, the completion of twenty-nine subjects means that the power was lower than anticipated. Despite these limitations, strengths include the fact that subjects were not taking any medications to manage their diabetes thereby eliminating a possible confounding effect on results, the matching of protein content between the SPI and MPI treatments and the inclusion of postprandial measures of glycaemic control.

In summary, consumption of soya protein for 8 weeks did not significantly affect fasting or postprandial measures of glycaemic control in a sample of twenty-nine adults with diet-controlled diabetes. The present study adds to the literature with its unique qualities of matching for protein content between the SPI and MPI treatments and including postprandial measures of glycaemic control. Information gained from the present study provides valuable insight for future direction of research exploring the effects of soya for the prevention and management of type 2 diabetes.

\section{Acknowledgements}

The authors gratefully acknowledge the subjects for their participation in the present study, the Human Nutraceutical Research Unit at the University of Guelph for use of their facility, Erin Balodis, Laura Beaton, Lauren Carde, Stephanie Hass, Mehrnoosh Kashani, Kelly Mascioli, Rachel Masters and Megan Olson for their help with data collection and data entry and Wendy Thomas for her technical assistance in the urinary isoflavone analyses. Funding was provided by the Heart and Stroke Foundation of Ontario (Grant \#NA5553) and the MPI and SPI treatment powders were provided by Solae LLC. C. P. G. co-coordinated the subject recruitment and data collection, performed the glucose and insulin laboratory analysis, assisted in the data and statistical analyses, summarised the results and worked on the manuscript preparation. E. A. P. co-coordinated the subject recruitment and data collection and contributed to the manuscript preparation. S. E. C. contributed to the study design, 
provided medical expertise throughout the subject recruitment and data collection and contributed to the manuscript preparation. G. A. D. contributed to the study design, provided statistical expertise throughout the statistical analysis and results interpretation and contributed to the manuscript preparation. J. W. L. performed the urinary isoflavone analyses and contributed to the manuscript preparation. A. M. D. designed the study, secured the funding, supervised the subject recruitment and data collection, supervised the glucose and insulin laboratory analyses, directed the data and statistical analyses, directed the interpretation of results and directed the manuscript preparation.

None of the authors had any conflicts of interest related to the research.

\section{References}

1. Zimmet P, Alberti KG \& Shaw J (2001) Global and societal implications of the diabetes epidemic. Nature 414, 782-787.

2. Zimmet P, Magliano D, Matsuzawa Y, et al. (2005) The metabolic syndrome: a global public health problem and a new definition. J Atheroscler Thromb 12, 295-300.

3. Pradhan A (2007) Obesity, metabolic syndrome, and type 2 diabetes: inflammatory basis of glucose metabolic disorders. Nutr Rev 65, S152-S156.

4. Alberti G, Zimmet P, Shaw J, et al. (2004) Type 2 diabetes in the young: the evolving epidemic: the international diabetes federation consensus workshop. Diabetes Care 27, 1798-1811.

5. King H, Aubert RE \& Herman WH (1998) Global burden of diabetes, 1995-2025: prevalence, numerical estimates, and projections. Diabetes Care 21, 1414-1431.

6. O'Brien JA, Patrick AR \& Caro JJ (2003) Cost of managing complications resulting from type 2 diabetes mellitus in Canada. BMC Health Serv Res 3, 7.

7. Bavenholm PN \& Efendic S (2006) Postprandial hyperglycaemia and vascular damage - the benefits of acarbose. Diab Vasc Dis Res 3, 72-79.

8. Dawson KG, Gomes D, Gerstein H, et al. (2002) The economic cost of diabetes in Canada, 1998. Diabetes Care $\mathbf{2 5}$, $1303-1307$.

9. Committee CDACPGE (2003) Canadian Diabetes Association 2003 Clinical Practice Guidelines for the Prevention and Management of Diabetes in Canada. Can J Diab 27, S1-S152.

10. Stratton IM, Adler AI, Neil HA, et al. (2000) Association of glycaemia with macrovascular and microvascular complications of type 2 diabetes (UKPDS 35): prospective observational study. Br Med J 321, 405-412.

11. Gaede P, Vedel P, Larsen N, et al. (2003) Multifactorial intervention and cardiovascular disease in patients with type 2 diabetes. N Engl J Med 348, 383-393.

12. Krook A, Holm I, Pettersson S, et al. (2003) Reduction of risk factors following lifestyle modification programme in subjects with type 2 (non-insulin dependent) diabetes mellitus. Clin Physiol Funct Imaging 23, 21-30.

13. Garg A, Bantle JP, Henry RR, et al. (1994) Effects of varying carbohydrate content of diet in patients with non-insulindependent diabetes mellitus. JAMA 271, 1421-1428.

14. Chandalia M, Garg A, Lutjohann D, et al. (2000) Beneficial effects of high dietary fiber intake in patients with type 2 diabetes mellitus. N Engl J Med 342, 1392-1398.

15. Sierra M, Garcia JJ, Fernandez N, et al. (2002) Therapeutic effects of psyllium in type 2 diabetic patients. Eur J Clin Nutr 56, 830-842

16. Mooradian AD, Failla M, Hoogwerf B, et al. (1994) Selected vitamins and minerals in diabetes. Diabetes Care 17, 464-479.
17. Robertson MD, Jackson KG, Fielding BA, et al. (2002) Acute effects of meal fatty acid composition on insulin sensitivity in healthy post-menopausal women. Br J Nutr 88, 635-640.

18. Paniagua JA, de la Sacristana AG, Sanchez E, et al. (2007) A MUFA-rich diet improves posprandial glucose, lipid and GLP-1 responses in insulin-resistant subjects. J Am Coll Nutr 26, 434-444.

19. Fujimoto WY, Leonetti DL, Kinyoun JL, et al. (1987) Prevalence of diabetes mellitus and impaired glucose tolerance among second-generation Japanese-American men. Diabetes 36, 721-729.

20. Fujimoto WY, Leonetti DL, Bergstrom RW, et al. (1991) Glucose intolerance and diabetic complications among Japaese-American women. Diabetes Res Clin Pract 13, 119-129.

21. Goodman-Gruen D \& Kritz-Silverstein D (2001) Usual dietary isoflavone intake is associated with cardiovascular disease risk factors in postmenopausal women. J Nutr 131, 1202-1206.

22. Villegas R, Gao YT, Yang G, et al. (2008) Legume and soy food intake and the incidence of type 2 diabetes in the Shanghai Women's Health Study. Am J Clin Nutr 87, 162-167.

23. Yang G, Shu XO, Jin F, et al. (2004) Soyfood consumption and risk of glycosuria: a cross-sectional study within the Shanghai Women's Health Study. Eur J Clin Nutr 58, 615-620.

24. Lavigne C, Marette A \& Jacques H (2000) Cod and soy proteins compared with casein improve glucose tolerance and insulin sensitivity in rats. Am J Physiol Endocrinol Metab 278, E491-E500.

25. Ascencio C, Torres N, Isoard-Acosta F, et al. (2004) Soy protein affects serum insulin and hepatic SREBP-1 mRNA and reduces fatty liver in rats. $J$ Nutr 134, 522-529.

26. Veloso RV, Latorraca MQ, Arantes VC, et al. (2008) Soybean diet improves insulin secretion through activation of cAMP/ PKA pathway in rats. J Nutr Biochem 19, 778-784.

27. Wagner JD, Cefalu WT, Anthony MS, et al. (1997) Dietary soy protein and estrogen replacement therapy improve cardiovascular risk factors and decrease aortic cholesteryl ester content in ovariectomized cynomolgus monkeys. Metabolism 46, 698-705.

28. Lee JS (2006) Effects of soy protein and genistein on blood glucose, antioxidant enzyme activities, and lipid profile in streptozotocin-induced diabetic rats. Life Sci 79, 1578-1584.

29. Davis J, Higginbotham A, O'Connor T, et al. (2007) Soy protein and isoflavones influence adiposity and development of metabolic syndrome in the obese male ZDF rat. Ann Nutr Metab 51, $42-52$

30. Ishihara K, Oyaizu S, Fukuchi Y, et al. (2003) A soybean peptide isolate diet promotes postprandial carbohydrate oxidation and energy expenditure in type II diabetic mice. J Nutr 133, 752-757.

31. Nordentoft I, Jeppesen PB, Hong J, et al. (2008) Increased insulin sensitivity and changes in the expression profile of key insulin regulatory genes and beta cell transcription factors in diabetic KKAy-mice after feeding with a soy bean protein rich diet high in isoflavone content. J Agric Food Chem 56, 4377-4385.

32. Ae Park S, Choi MS, Cho SY, et al. (2006) Genistein and daidzein modulate hepatic glucose and lipid regulating enzyme activities in C57BL/KsJ-db/db mice. Life Sci 79, 1207-1213.

33. Teixeira SR, Tappenden KA, Carson L, et al. (2004) Isolated soy protein consumption reduces urinary albumin excretion and improves the serum lipid profile in men with type 2 diabetes mellitus and nephropathy. $J$ Nutr 134, 1874-1880.

34. Azadbakht L, Atabak S \& Esmaillzadeh A (2008) Soy protein intake, cardiorenal indices, and C-reactive protein in type 2 diabetes with nephropathy: a longitudinal randomized clinical trial. Diabetes Care 31, 648-654. 
35. Azadbakht L, Shakerhosseini R, Atabak S, et al. (2003) Beneficiary effect of dietary soy protein on lowering plasma levels of lipid and improving kidney function in type II diabetes with nephropathy. Eur J Clin Nutr 57, 1292-1294.

36. Anderson JW, Blake JE, Turner J, et al. (1998) Effects of soy protein on renal function and proteinuria in patients with type 2 diabetes. Am J Clin Nutr 68, 1347S-1353S.

37. Oh HY, Kim SS, Chung HY, et al. (2005) Isoflavone supplements exert hormonal and antioxidant effects in postmenopausal Korean women with diabetic retinopathy. J Med Food 8, 1-7.

38. Li Z, Hong K, Saltsman P, et al. (2005) Long-term efficacy of soy-based meal replacements vs an individualized diet plan in obese type II DM patients: relative effects on weight loss, metabolic parameters, and C-reactive protein. Eur J Clin Nutr 59, 411-418.

39. Hermansen K, Sondergaard M, Hoie L, et al. (2001) Beneficial effects of a soy-based dietary supplement on lipid levels and cardiovascular risk markers in type 2 diabetic subjects. Diabetes Care 24, 228-233.

40. Howes JB, Tran D, Brillante D, et al. (2003) Effects of dietary supplementation with isoflavones from red clover on ambulatory blood pressure and endothelial function in postmenopausal type 2 diabetes. Diabetes Obes Metab 5, 325-332.

41. Mahalko JR, Sandstead HH, Johnson LK, et al. (1984) Effect of consuming fiber from corn bran, soy hulls, or apple powder on glucose tolerance and plasma lipids in type II diabetes. Am J Clin Nutr 39, 25-34.

42. Ristic Medic D, Ristic V, Arsic A, et al. (2006) Effects of soybean D-LeciVita product on serum lipids and fatty acid composition in type 2 diabetic patients with hyperlipidemia. Nutr Metab Cardiovasc Dis 16, 395-404.

43. Shahbazian H, Reza A, Javad S, et al. (2007) Beneficial effects of soy protein isoflavones on lipid and blood glucose concentrations in type 2 diabetic subjects. Saudi Med $J \mathbf{2 8}$, 652-654.

44. Tsai AC, Vinik AI, Lasichak A, et al. (1987) Effects of soy polysaccharide on postprandial plasma glucose, insulin, glucagon, pancreatic polypeptide, somatostatin, and triglyceride in obese diabetic patients. Am J Clin Nutr 45, 596-601.

45. Gonzalez S, Jayagopal V, Kilpatrick ES, et al. (2007) Effects of isoflavone dietary supplementation on cardiovascular risk factors in type 2 diabetes. Diabetes Care 30, 1871-1873.

46. Jayagopal V, Albertazzi P, Kilpatrick ES, et al. (2002) Beneficial effects of soy phytoestrogen intake in postmenopausal women with type 2 diabetes. Diabetes Care 25, 1709-1714.

47. Gannon MC, Nuttall FQ, Saeed A, et al. (2003) An increase in dietary protein improves the blood glucose response in persons with type 2 diabetes. Am J Clin Nutr 78, 734-741.

48. Gannon MC \& Nuttall FQ (2006) Control of blood glucose in type 2 diabetes without weight loss by modification of diet composition. Nutr Metab (Lond) 3, 16.

49. Layman DK, Clifton P, Gannon MC, et al. (2008) Protein in optimal health: heart disease and type 2 diabetes. Am J Clin Nutr 87, 1571S-1575S.

50. Lampe JW, Skor HE, Li S, et al. (2001) Wheat bran and soy protein feeding do not alter urinary excretion of the isoflavan equol in premenopausal women. J Nutr 131, 740-744.

51. Muniyappa R, Lee S, Chen H, et al. (2008) Current approaches for assessing insulin sensitivity and resistance in vivo: advantages, limitations, and appropriate usage. Am J Physiol Endocrinol Metab 294, E15-E26.

52. Chen H, Sullivan G \& Quon MJ (2005) Assessing the predictive accuracy of QUICKI as a surrogate index for insulin sensitivity using a calibration model. Diabetes 54, 1914-1925.

53. Phillips DI, Clark PM, Hales CN, et al. (1994) Understanding oral glucose tolerance: comparison of glucose or insulin measurements during the oral glucose tolerance test with specific measurements of insulin resistance and insulin secretion. Diabet Med 11, 286-292.

54. Rowland IR, Wiseman H, Sanders TA, et al. (2000) Interindividual variation in metabolism of soy isoflavones and lignans: influence of habitual diet on equol production by the gut microflora. Nutr Cancer 36, 27-32.

55. Markovic TP, Jenkins AB, Campbell LV, et al. (1998) The determinants of glycemic responses to diet restriction and weight loss in obesity and NIDDM. Diabetes Care 21, 687-694.

56. Pittas AG, Lau J, Hu FB, et al. (2007) The role of vitamin D and calcium in type 2 diabetes. A systematic review and meta-analysis. J Clin Endocrinol Metab 92, 2017-2029.

57. Xu X, Duncan AM, Merz BE, et al. (1998) Effects of soy isoflavones on estrogen and phytoestrogen metabolism in premenopausal women. Cancer Epidemiol Biomarkers Prev 7, 1101-1108.

58. Lampe JW, Karr SC, Hutchins AM, et al. (1998) Urinary equol excretion with a soy challenge: influence of habitual diet. Proc Soc Exp Biol Med 217, 335-339.

59. Kelly GE, Nelson C, Waring MA, et al. (1993) Metabolites of dietary (soya) isoflavones in human urine. Clin Chim Acta 223, 9-22.

60. Hall WL, Vafeiadou K, Hallund J, et al. (2006) Soy-isoflavoneenriched foods and markers of lipid and glucose metabolism in postmenopausal women: interactions with genotype and equol production. Am J Clin Nutr 83, 592-600.

61. von Hertzen L, Forsblom C, Stumpf K, et al. (2004) Highly elevated serum phyto-oestrogen concentrations in patients with diabetic nephropathy. J Intern Med 255, 602-609.

62. American Diabetes Association (ADA) (2002) Tests of glycemia in diabetes. Position statement. Diabetes Care 25, S97-S99.

63. Heilbronn LK, Noakes M \& Clifton PM (2002) The effect of high- and low-glycemic index energy restricted diets on plasma lipid and glucose profiles in type 2 diabetic subjects with varying glycemic control. J Am Coll Nutr 21, 120-127.

64. Azadbakht L, Kimiagar M, Mehrabi Y, et al. (2007) Soy inclusion in the diet improves features of the metabolic syndrome: a randomized crossover study in postmenopausal women. Am J Clin Nutr 85, 735-741.

65. Avignon A, Radauceanu A \& Monnier L (1997) Nonfasting plasma glucose is a better marker of diabetic control than fasting plasma glucose in type 2 diabetes. Diabetes Care 20, $1822-1826$.

66. Kang MJ, Kim JI, Yoon SY, et al. (2006) Pinitol from soybeans reduces postprandial blood glucose in patients with type 2 diabetes mellitus. J Med Food 9, 182-186.

67. Harris SB, Ekoe JM, Zdanowicz Y, et al. (2005) Glycemic control and morbidity in the Canadian primary care setting (results of the diabetes in Canada evaluation study). Diabetes Res Clin Pract 70, 90-97. 